\title{
Determinants of Foreign Direct Investment in Developed and Developing Countries: Impact of Political Stability
}

Stable political environment and prominent development of political institutions increase foreign direct investment flows by providing lower risks for investors. However, this impact can vary according to the development of the country. This study aims to investigate the impact of various indicators of political stability on foreign direct investment attraction for different economies distinguished by their development level. Our database includes 66 FDI-recipient countries and 98 FDI-investing countries for the period from 2001 to 2018. By applying the gravity approach and Poisson Pseudo Maximum Likelihood method with instrumental variables (IV PPML), we model bilateral FDI flows, incorporating variables reflecting various aspects of political stability formed by the principal components analysis. Interestingly, we found mixed results regarding the impact of political stability on FDI flows. In particular, political stability indicators were found to be insignificant, when analysing the bilateral FDI flows for the group of developed economies. We obtained similar result for the group of developing economies. However, political stability variables significantly influence FDI flows for countries with different development level, confirming the hypothesis that countries' development affects bilateral FDI flows. Besides, we discover the significant difference between developed and developing countries referring to FDI-investors. Based on the obtained results, we highlight a few policy implications for developing and developed economies.

Keywords: foreign direct investment, political stability, economic development, gravity model, IV PPML, Pseudo Poisson Maximum Likelihood method, principal component analysis, developing economies, developed economies, bilateral FDI flows

\section{Acknowledgments}

The article has been prepared with the support of the grant of the President of Russian Federation "Institutional determinants of foreign direct investment inflows: country and region level analysis" (project No. MD-6402.2018.6).

For citation: Vasilyeva, R. I. \& Mariev, O. S. (2021). Determinants of Foreign Direct Investment in Developed and Developing Countries: Impact of Political Stability. Ekonomika regiona [Economy of region], 17(4), 1390-1404, https://doi. org/10.17059/ekon.reg.2021-4-24.

\footnotetext{
${ }^{1}$ (c) Vasilyeva R. I., Mariev O. S. Text. 2021.
} 


\author{
Р. И. Васильева ${ }^{a)}$, О. С. Мариев б) \\ а, б) Уральский федеральный университет имени первого Президента России Б. Н. Ельцина, \\ Екатеринбург, Российская Федерация \\ a) https://orcid.org/0000-0001-5539-3145, rogneda.groznykh@urfu.ru \\ 6) https://orcid.org/0000-0002-9745-8434
}

\title{
Влияние политической стабильности на прямые иностранные инвестиции в развитых и развивающихся странах
}

Стабильная политическая и институциональная среда способствует увеличению потоков прямых иностранных инвестиций в экономику благодаря снижению потенциальных рисков для иностранного инвестора. Однако это влияние может варьироваться в зависимости от уровня развития страны. Основная цзель исследования заключается в оценке влияния показателей политической стабильности на привлечение прямых иностранных инвестиций для стран, различающихся по уровню экономического развития. Эконометрический анализ проведен на основе базы данных по двусторонним потокам прямых иностранных инвестиций по 66 странам - получателям ПИИ и 98 странам - инвесторам ПИИ за период с 2001 по 2018 г2. Эмпирический анализ, представленный в данном исследовании, основан на гравитационном подходе для получения достоверных эконометрических оценок. Основным методом эконометрического моделирования является метод псевдомаксимального правдоподобия Пуассона с инструментальными переменными (IV PPML). Для структурирования показателей политической стабильности применяется метод главных компонент. Выявлено неоднозначное влияние политической стабильности на потоки прямых иностранных инвестиций. В частности, показатели политической стабильности не играют большой роли для установления двусторонних потоков ПИИ между развитыми странами; аналогичная ситуация наблюдается в странах с развивающейся экономикой. Однако показатели политической стабильности увеличивают приток прямых иностранных инвестиций для стран с разным уровнем развития, подтверждая гипотезу о влиянии развитости экономики. Кроме того, были обнаружены существенные различия в значимости факторов между ПИИинвесторами развитых и развивающихся стран. На основе результатов эмпирического исследования предлагаются рекомендации по совершенствованию политики в области привлечения прямых иностранных инвестиций.

Ключевые слова: прямые иностранные инвестиции, политическая стабильность, экономическое развитие, гравитационная модель, метод псевдомаксимального правдоподобия Пуассона с инструментальными переменными, метод псевдомаксимального правдоподобия Пуассона, метод главных компонент, развивающиеся экономики, развитые экономики, двусторонние потоки ПИИ

\section{Благодарность}

Исследование было поддержано грантом Президента РФ для государственной поддержки молодых докторов наук «Институииональные факторы привлечения прямых зарубежных инвестиицй: страновой и региональный анализ» (проект № МД-6402.2018.6).

Для цитирования: Васильева Р. И., Мариев О. С. Влияние политической стабильности на прямые иностранные инвестиции в развитых и развивающихся странах. Экономика региона. 2021. Т. 17, вып. 4. С. 1390-1404. https://doi. org/10.17059/ekon.reg.2021-4-24.

\section{Introduction}

Nowadays, foreign direct investment is an integral part of an open and efficient international economic environment. In addition, foreign direct investment stimulates economic growth and provides sustainable, highly-qualified and balanced economic development. Considering the fact that developing economies are striving to achieve higher development and economic growth rates, attraction of foreign direct investment might be even more significant for these economies. On the other hand, foreign direct investment is associ- ated with the negative circumstances, especially for developing countries, as it implies the control of the enterprise by another country. In addition, the profit obtained in the FDI-recipient country is transferred abroad, which can harm the economy. It is worth to note that for many countries foreign direct investment is a possibility to get new technologies, update and promote production capacities, gain methods of effective management and provide wider employment opportunities [1, 2]. In terms of developing economies, foreign direct investment is seen as an instrument of successful 
integration into international economics and value-added manufacturing chains.

Recent studies highlight a wide range of determinants of foreign direct investment, which are valuable in its attraction. All factors can be defined as macroeconomic factors, government policy towards foreign direct investment, intra-firm and institutional factors. To obtain higher values of foreign direct investment, research results on their determinants can be implemented by receiving and investing countries. Therefore, the study has a considerable scientific and applied significance.

In order to benefit from foreign direct investment, states need to pursue appropriate public policies that will contribute to the creation of favourable conditions for investors by ensuring political and financial stability, as well as protection of their rights, for which the institutional environment in the country is responsible. In the last century, many researchers have been interested in institutional factors, in particular, in the aspect of foreign direct investment attraction [3].

This article aims to examine the impact of political stability on bilateral flows of foreign direct investment. First, it is considered that the lower political stability causes higher risks for an investor; therefore, it can be assumed as additional tax burden. Second, as Daude and Stein [5] mentioned in their research, political instability increases the uncertainty faced by foreign investors, which negatively affects foreign direct investment inflows. Buchanan, Le and Rishi [4] hypothesised that weaker institutional development leads to a decrease in political stability, which increases volatility of foreign direct investment flows. Improvement of the institutional quality and political stability makes national economy more competitive and, therefore, increases the amount of foreign direct investment outflows. At the same time, enhancement of political stability in the recipient country should raise incoming foreign direct investment $[4,5]$.

Therefore, the main aim of the research is to study the impact of political stability on foreign direct investment attraction considering the development of the observed countries. In order to obtain robust results, instrumental econometric analysis was applied. For the analysis, we used a dataset on bilateral foreign direct investment flows, which includes 66 recipient countries and 98 investing countries. For political stability indicators, twelve indices estimated by PRS-Group were implemented: "Government Stability", "Socioeconomic Conditions", "Investment Profile”, "Internal Conflict”, "External Conflict”,
"Corruption", "Military in Politics", "Religious Tensions", "Law and Order", "Ethnic Tensions", "Democratic Accountability" and "Bureaucracy Quality". These variables were converted into three larger indicators applying principal component analysis. The model was built based on the gravity approach. Pseudo Poisson Maximum Likelihood method with instrumental variables was implemented in order to achieve robust estimations,.

The paper contains five parts, including the introduction. The second part is devoted to the literature review on the issue, in particular, on the discussion of the existing empirical studies. The following chapter describes the methodology used in the research and construction of the econometric model together with descriptive statistics and description of the variables used for the econometric estimations. The next part presents the results of the research. The conclusions are provided in the last part to highlight possible policy implications of the obtained results.

\section{Literature Review}

The empirical literature on determinants of foreign direct investment emphasises the significance of macroeconomic indicators, geographical factors and intra-firm indicators. According to macroeconomic factors affecting foreign direct investment attraction, many researchers confirm the impact of openness of FDI-recipient economy [1], inflation rate and labour expenditures [6], government expenditures [7], international trade, considering the volumes of export and import [8], tax rates [9], national innovation development [10], government expenditures for education [11], infrastructural development [12], etc.

The following indicators are frequently considered as geographical determinants of foreign direct investment flows: common language $[9,13]$, common border [14], existence of common history, natural resources abundance and regional characteristics in the country $[15,16,17,18]$. These factors also indicate the resemblance of the countries. Additionally, in major studies, the scent of previous colony is also accounted as a geographical indicator.

Alternative studies on foreign direct investment attraction consider firm level characteristics, which are associated with technological advance of a company, transportation costs [19], growth of returns on scale, operation costs and size of the market [8]. Considering the research of intra-firm factors affecting inward and outward foreign direct investment flows, all the factors can be divided into pure companies' characteris- 
tics and factors, which are proposed by the local and foreign government. As most of the intra-firm costs were reduced, investors became more aware of institutional environment that creates sustainable and suitable business conditions for foreign firms entering the national markets.

Therefore, due to increasing attitude towards institutional determinants, which can be associated with integration processes in the world economics, a large number of studies on the impact of institutional factors on foreign direct investment flows has appeared recently. Given that, the current research is aimed at studying more precisely this group of factors describing them with more diligence. One of the first works on empirical significance of institutional determinants has revealed that political instability leads to a decrease in foreign direct investment inflows [20]. The study by Gastanaga, Nugent and Pashamova reveals that lower level of corruption, lower nationalisation risk and juridical protection of transactions increase incoming foreign direct investment [21]. Most of the premier research examined the impact of particular institutional factors on foreign direct investment inflows. For instance, Wei confirmed that the level of corruption in the country negatively affects the decision of foreign investors, specifically, transnational companies, to organise production in the country [22]. Jensen [23] and Ahlquist [24] argue that countries with more advanced democracies attract more foreign direct investment. Along with that, inefficient institutional environment, which considers corruption, political instability and insufficient legislative regulation, leads to the reduction of foreign direct investment flows to the recipient country [25]. According to Daude and Stein, such indicators as lack of cruelty from the ruling party, high-quality government regulation, control over corruption and social infrastructure creation increase foreign direct investment inflows, while unpredictability in economic changes and financial policy, excessive administrative burdens and non-compliance with government obligations severely them [5]. Gani obtained similar results: the evidence shows that improved control over corruption, political stability, regulation quality, and government effectiveness stimulate the flow of foreign direct investment into the country [26].

The prior studies were conducted applying qualitative institutional indicators. Nevertheless, contemporary research is frequently using alternative institutional dimensions. Some authors concluded that the calculation of institutional indices gives more indicative results than the use of quantitative variables [27]. Proxy variables, such as the number of revolutions and attempts on government representatives, are seen as less indicative, since there might not have been revolutions or attacks in some countries. Plenty of studies consider aggregate indicators that consist of various aspects of an institutional development of a country as determinants of foreign direct investment inflows. Globerman and Shapiro, using an index that includes indicators of corruption, rule of law, regulation quality, and political stability, show that an increase in the indices contributes to foreign direct investment inflows to the country [28]. Buchanan, Le and Rishi show that the institutional quality index has a positive effect on foreign direct investment inflows and negatively affects the volatility of these flows [4]. Foreign direct investment inflows also depend on legal system efficiency $[29,30]$, regulation and entry barriers [31] and property rights protection [32]. Ali, Fiess and MacDonald confirmed that international country risk index significantly affects foreign direct investment inflows [33].

Although institutional indicators put forward a primary concern, traditional factors are still significant in foreign direct investment attraction [34]. Therefore, they should be controlled for economic factors [35, 36]. Meanwhile, an addition of institutional indicators into an econometric model can significantly decrease the effect of macroeconomic variables on inward foreign direct investment flows [37].

However, a few empirical studies do not support the traditional view of the positive impact of institutional variables on the inward foreign direct investment flows. The research work of Asiedu shows that neither political risk nor expropriation risk have a statistically significant effect on foreign direct investment inflows [38]. Noorbakhsh, Paloni and Youssef were unable to identify a statistically significant relationship between democracy, political risk, and foreign direct investment inflows [11]. Some studies conclude that the level of democracy in the host country, corruption, legal system and bureaucracy quality negatively affect inward foreign direct investment flows [39, 40]. Using an institutional development index that includes indicators of corruption, political stability, bureaucracy and the effectiveness of the legal system, Wheeler and Mody identified no relationship between the index and the decision of transnational companies (TNCs) to invest in the country [12]. Similar results were obtained in the work of Asiedu based on an aggregate indicator that includes the security of contracts, the presence of restrictions on the export of capital and the average delay in payments [41]. 


\section{Data and Econometric Methodology}

\section{Gravity Approach}

Gravity approach is one of the most common techniques in empirical literature for modelling foreign direct investment flows. It was first used by Tinbergen for modelling cross-country trade flows [42]. The author concluded that the income of countries trading with each other has a positive effect on export volumes in these countries, while the distance negatively affects the amount of trade due to a decrease in the level of trade between the countries. This model has become widespread due to the high accuracy of assessment of the indicators. Later, Brainard implemented the gravity approach for studying foreign direct investment flows [43]. The model was based on three main variables, indicating the size of economies (FDI-investor and FDI-recipient), that are considered in current research as the gravity variables. Therefore, the gravity model can be represented with equation 1 :

$$
F D I_{i j t}=\frac{G D P_{i t} \times G D P_{j t}}{D_{i j}},
$$

where $F D I_{i j t}$ is a flow of foreign direct investment from country $j$ to country $i$ in a year $t, G D P_{i t}$ and $G D P_{i t}$ is the size (gross domestic product $(G D P)$ ) of the countries $i$ and $j$ in the year $t, D_{i j}$ is the distance between the countries.

Theoretical reasoning of implementing the gravity approach to bilateral foreign direct investment flows is highlighted in neoclassical models [44], contemporary models of horizontal foreign direct investment $[19,45]$, contemporary models of vertical foreign direct investment [46, 47], and also the latest models with heterogeneous firms $[48,49,13]$.

\section{Research Hypothesis}

In order to solve the problems and overcome the limitations stated in the previous part, the following research hypotheses were formulated.

Hypothesis 1. The development of sustainable political environment increases inward foreign direct investment flows. First, the higher level of political stability leads to an increase in investors' property rights security. Second, it should decrease operational and bureaucratic costs for foreign investors. Therefore, higher indicators of political stability might increase inward foreign direct investment.

Hypothesis 2. The impact and significance of political stability differs according to the development level of FDI-recipient and FDI-investing countries. Developed economies are associated with better institutional environment and higher political stability indicators. Hence, for developed investor countries, the political stability indicator should be more important, while developing economies strive to invest to more politically stable countries. In this regard, if countries have the same development level, then other factors should be more significant rather than institutional. At the same time, country risks are more significant for companies from developed countries investing to developing ones, because the ability of companies from developed countries to withstand an unfavourable environment associated with weak institutions is at a lower level compared to companies from countries with weaker institutions that exist in such an environment. Simultaneously, for companies from less developed countries, the level of institutional development of other states is probably less significant, because they do not face greater risks of doing business abroad compared to their home country.

\section{Data and Econometric Model}

While constructing an econometric model, the gravity approach was implemented. Therefore, $F D I_{i j t}$ is a dependent variable, which indicates flows for foreign direct investment from country $i$ to country $j$ in a time $t$.

Three different types of indicators are used as independent variables. The first ones are "gravity" variables, applied in the gravity model. They indicate the size of economies and distance between them:

$-\lg d p I M P_{i t}-\operatorname{logarithm}$ of gross domestic product (GDP) of FDI-recipient country (mln doll. USA);

- $\lg d p E X P_{i t}$ - logarithm of GDP of FDIinvesting country (mln doll. USA);

- ldist $_{i j}$ - logarithm of distance between FDIrecipient and FDI-investing countries $(\mathrm{km})$.

Accounting for gravity model assumptions, the correct and robust estimations should provide significant and positive $\beta$-coefficients for variables, indicating economies' size, while the coefficient for distance between FDI-recipient and FDIinvesting countries should have significant and negative sign.

Another group of variables represented as a vector of various indices accounts for institutional indicators, which are included into the dataset in order to test the stated hypothesis. For intuitional variables, we use the indices of political stability PoliticalStability $_{i t}$ calculated by PRSGroup, which includes twelve different indicators: "Government Stability", "Socioeconomic Conditions", "Investment Profile", "Internal 
Conflict”, “External Conflict”, “Corruption”, "Military in Politics", "Religious Tensions", "Law and Order", "Ethnic Tensions", "Democratic Accountability" and "Bureaucracy Quality".

The last are control variables, which are included into the model in order to get unbiased estimations of the impact of political stability on foreign direct investment inflows [35]:

- Openness ${ }_{i t}$ - an indicator of trade openness of a FDI-recipient country, which represents the ratio of the sum of export and import to country's $G D P$ (in \%). The level of economic openness indicates liberal trade regime in the country, less economic barriers for a foreign investor and greater degree of country involvement into international economic relations [50].

- Inflation ${ }_{\text {it }}$ - inflation rate in a FDI-recipient country (\%). This indicator is included in thwthe econometric model as a macroeconomic factor, indicating economic stability in the country, and a control for institutional variables.

- Exch $_{i t}$ - exchange rate in a FDI-recipient country (ratio to US dollar). This indicator is included in the econometric model as a macroeconomic factor and a control variable

The control variables are also implemented for robustness check, represented in the section "Results and Discussion".

To summarise, the final model should be presented as follows (equation 2):

$$
F D I_{i j t}=\exp \left(\begin{array}{c}
\beta_{0}+\beta_{1} \lg \text { dpIMP }_{i t}+\beta_{2} \lg d p E X P_{j t}+ \\
+\beta_{3} \text { Idist }_{i j}+\beta_{4} \text { Openness }_{i t}+ \\
+\beta_{5} \text { Inflation }_{i t}+\beta_{6} \text { IExch }_{i t}+ \\
+\beta_{i} \text { PoliticalStability }_{i t}
\end{array}\right) \varepsilon_{i t},(2)
$$

where $\beta_{0}$ is a constant, $\beta_{i}$ is coefficients of explanatory variables, $\varepsilon_{i t}$ is the regression error term.

The panel dataset used for the econometric estimation is compiled based on open sources and includes 116564 observations over 98 FDIexporting countries and 66 FDI-recipient countries for the period from 2001 to 2018. Information on cross-country FDI flows was obtained from the IMF Coordinated Direct Investment Survey $(C D I S)^{1}$. The offshore countries are not included into the dataset due to tax evasion activities that do not have a positive impact on the economy of the recipient country. Moreover, the data on offshore countries are confidential and not published in the open sources. Country GDP data, inflation rate, and trade openness are obtained from the

\footnotetext{
${ }^{1}$ International Monetary Fund. (2019). IMF data. Coordinated Direct Investment Survey. Retrieved from: https://data.imf. org/?sk=40313609-F037-48C1-84B1-E1F1CE54D6D5 (Date of access: 15.01.2020)
}

World Bank database ${ }^{2}$, the distance between capitals is taken from the Meyer and Zignago database [14].

To study the influence of political stability on the inward foreign direct investment flows, institutional indices compiled by the PRS-Group (Political Risk Services) were selected. This agency is the developer of the International Country Risk Guide (ICRG) index, which shows the level of risks in the country for a potential investor and consists of macroeconomic, market, institutional and political indicators.

\section{Econometric Methodology}

The gravity model is widely used in analysis of foreign direct investment inflows. It has shown its accuracy in assessment of econometric models. Still, there is a discussion in empirical literature on econometric methods that are suitable for gravity model estimations. Currently, one of the most advanced and suitable methods for the gravity model estimation is Poisson Pseudo Maximum Likelihood (PPML), which deals with highly heterogeneous data and zero observations in a dependent variable. It was first applied by Silva and Tenreyro in 2006 [51]. This approach has confirmed its efficiency in later works [52]. PPML is an interpretation of the generalised method of moments (GMM) from a variety of maximum likelihood methods, and the generalised method of moments is often used to correct the biasness due to the endogeneity of explanatory variables. PPML with instrumental variables (IV PPML) estimates the parameters of a Poisson regression model in which some repressors are endogenous.

Due to including political stability variables into the regression, a problem of endogeneity can occur in the estimations, which cause bias and regression estimations inconsistency. Endogeneity problem is caused by simultaneous influence of political stability indicators on foreign direct investment and vice versa: larger values of inward foreign direct investment might lead to an enhancement of political stability in the country. In order to solve this problem and obtain unbiased estimations, PPML method with instrumental variables (IV PPML) was implemented. Four dummy variables indicating a country's belonging to one of four legal systems - Germanic, French, AngloSaxon, or Scandinavian - were applied as instrumental. The intuition of implementation of the mentioned instruments consists of historical im-

\footnotetext{
2 World Bank (2019). Retrieved from: https://databank. worldbank.org/indicator/ BN.KLT.DINV.CD/1ff4a498/ Popular-Indicators (Date of access: 18.05.2020).
} 
pact of legal system on the current institutional environment in the country [5].

In a situation when several institutional variables are included in an econometric model, the issue on their inclusion in one regression arises. On the one hand, the simultaneous inclusion of all indicators leads to biased estimates as a result of multicollinearity; on the other hand, the inclusion of indicators in turn will increase the number of regressions in the study and can lead to difficulties when interpreting results. Therefore, in current research, the method of principal component analysis was implemented in order to structure the political stability indicators and obtain a sufficient amount of institutional indicators [53, 54].

\section{Data Description}

The descriptive statistics are represented in Table 1. For indicators "Government Stability", "Socioeconomic Conditions", "Investment Profile", "Internal Conflict" and "External Conflict" the minimum value is 0 , which indicates the highest risk and the maximum value is 12 , which indicates the better institutional environment and lower risks for an investor. For indicators "Corruption", "Military in Politics", "Religious Tensions", "Law and Order", "Ethnic Tensions" and "Democratic Accountability" the minimum value is 0 , which indicates the highest risk and the maximum value is 6 , which indicates better institutional envi- ronment. The maximum value of "Bureaucracy Quality" is 4, which indicates better bureaucratic regulation in the country.

Taking into account the existence of 12 different political stability indicators, which are associated with the multicollinearity problem, we implement the factor analysis, more specifically, principal component analysis, to solve the stated issue. The estimation results are discussed in the following section.

\section{Results and Discussion}

\section{Principal Component Analysis}

The principal components analysis was conducted for structuring political stability indicators, which initially comprise twelve various indicators: "Government Stability", "Socioeconomic Conditions", "Investment Profile", "Internal Conflict", "External Conflict", "Corruption", "Military in Politics", "Religious Tensions", "Law and Order", "Ethnic Tensions", "Democratic Accountability" and "Bureaucracy Quality".

The results show that first three components have the highest eigenvalues and explain the variation by $70.35 \%$. According to Table 2 and scree plot (Figure 1), the sufficient number of factors is 3 ; therefore, all 12 political stability indicators can be integrated into 3 indices.

The scree plot shows that after the third component, eigenvalues drop below 1 , indicating that

Table 1

Descriptive statistics of gravity, institutional and control variables for all countries in 2000-2018

\begin{tabular}{|l|c|c|c|c|c|}
\hline \multicolumn{1}{|c|}{ Variable } & Mean & Std. Dev. & Min & Max & Obs. \\
\hline FDI & 96.805 & 2954.864 & -126665.5 & 268457.3 & 116564 \\
\hline Log gdp of importer & 11.983 & 1.919 & 7.145 & 16.838 & 116564 \\
\hline Log gdp of exporter & 11.641 & 1.937 & 5.68 & 16.838 & 116564 \\
\hline Trade Openness & 82.365 & 37.656 & 19.798 & 221.158 & 116564 \\
\hline Log of distance & 8.51 & 0.916 & 4.0879 & 9.892 & 116564 \\
\hline Inflation & 4.891 & 6.257 & -4.478 & 95.005 & 116564 \\
\hline Exchange rate & 281.291 & 1343.608 & 0.139 & 14236.94 & 116564 \\
\hline Government Stability (GS) & 7.964 & 1.468 & 4.042 & 12 & 116564 \\
\hline Socioeconomic Conditions (SC) & 6.562 & 2.337 & 1 & 11 & 116564 \\
\hline Investment Profile (IP) & 9.208 & 2.037 & 0.083 & 12 & 116564 \\
\hline Internal Conflict (IC) & 9.591 & 1.499 & 4.083 & 12 & 116564 \\
\hline External Conflict (EC) & 10.018 & 1.214 & 5.5 & 12 & 116564 \\
\hline Corruption (CR) & 3.031 & 1.260 & 1 & 6 & 116564 \\
\hline Military in Politics (MP) & 4.617 & 1.336 & 0 & 6 & 116564 \\
\hline Religious Tensions (RT) & 4.849 & 1.257 & 0.5 & 6 & 116564 \\
\hline Law and Order (LO) & 4.134 & 1.253 & 1 & 6 & 116564 \\
\hline Ethnic Tensions (ET) & 4.047 & 1.223 & 1 & 6 & 116564 \\
\hline Democratic Accountability (DA) & 4.729 & 1.415 & 0 & 6 & 116564 \\
\hline Bureaucracy Quality (BQ) & 2.668 & .985 & 1 & 4 & 116564 \\
\hline
\end{tabular}

Source: Authors' calculations based on data provided by International Monetary Fund, World Bank and PRS-Group. 
Component eigenvalues for the principal component analysis

\begin{tabular}{|l|c|c|c|c|}
\hline \multicolumn{1}{|c|}{ Component } & Eigenvalue & Difference & Proportion & Cumulative \\
\hline Component1 & 5.74107 & 4.22155 & 0.4784 & 0.4784 \\
\hline Component2 & 1.51952 & .338277 & 0.1266 & 0.6050 \\
\hline Component3 & 1.18124 & .27458 & 0.0984 & 0.7035 \\
\hline Component4 & .906663 & .360483 & 0.0756 & 0.7790 \\
\hline Component5 & .546179 & .0489946 & 0.0455 & 0.8246 \\
\hline Component6 & .497185 & .0873594 & 0.0414 & 0.8660 \\
\hline Component7 & .409825 & .0516209 & 0.0342 & 0.9001 \\
\hline Component8 & .358205 & .109915 & 0.0299 & 0.9300 \\
\hline Component9 & .248289 & .0109561 & 0.0207 & 0.9507 \\
\hline Component10 & .237333 & .0339284 & 0.0198 & 0.9705 \\
\hline Component11 & .203405 & .0523188 & 0.0170 & 0.9874 \\
\hline Component12 & .151086 &. & 0.0126 & 1.0000 \\
\hline
\end{tabular}

Source: Authors' calculations based on institutional data provided by PRS-Group.

Table 3

Rotation results for the principal component analysis

\begin{tabular}{|l|c|c|c|c|}
\hline \multicolumn{1}{|c|}{ Variable } & Comp1 & Comp2 & Comp3 & Unexplained \\
\hline Government Stability (GS) & & & 0.813 & 0.195 \\
\hline Socioeconomic Conditions (SC) & 0.443 & & & 0.237 \\
\hline Investment Profile (IP) & 0.367 & & & 0.346 \\
\hline Internal Conflict (IC) & & 0.479 & & 0.210 \\
\hline External Conflict (EC) & & 0.437 & & 0.529 \\
\hline Corruption (CR) & 0.418 & & & 0.223 \\
\hline Military in Politics (MP) & & 0.393 & & 0.193 \\
\hline Religious Tensions (RT) & & 0.480 & & 0.391 \\
\hline Law and Order (LO) & 0.419 & & & 0.269 \\
\hline Ethnic Tensions (ET) & & 0.426 & & 0.522 \\
\hline Democratic Accountability (DA) & & & -0.451 & 0.256 \\
\hline Bureaucracy Quality (BQ) & 0.451 & & & 0.18 \\
\hline
\end{tabular}

Source: Authors' calculations based on institutional data provided by PRS-Group.

New variables obtained from PCA and their structure

\begin{tabular}{|l|l|l|}
\hline \multicolumn{3}{|c|}{ New variables obtained from PCA } \\
\hline Government effectiveness & Conflicts and external policy & Government Stability and Democracy \\
\hline \multicolumn{3}{|c|}{ Structure } \\
\hline Socioeconomic Conditions (SC) & Internal Conflict (IC) & Government Stability (GS) \\
\hline Investment Profile (IP) & External Conflict (EC) & Democratic Accountability (DA) \\
\hline Corruption (CR) & Military in Politics (MP) & \\
\hline Law and Order (LO) & Religious Tensions (RT) & \\
\hline Bureaucracy Quality (BQ) & Ethnic Tensions (ET) & \\
\hline
\end{tabular}

Source: Authors' calculations based on institutional data provided by PRS-Group.

all political stability indicators should be transformed into 3 indicators.

After determining the number of components based on the principal component analysis, it was specified, which indicators will be included in each factor. The rotation results are represented in Table 3.

According to the principal component analysis, the first index includes "Socioeconomic
Conditions", "Investment Profile", "Corruption", "Law and Order" and "Bureaucracy Quality" indicators, which coincide with internal political environment; therefore, the first component is named "Government effectiveness". The representation of the principal component analysis is provided in Table 4.

The second component includes "Internal Conflict", "External Conflict", "Military in Politics", 


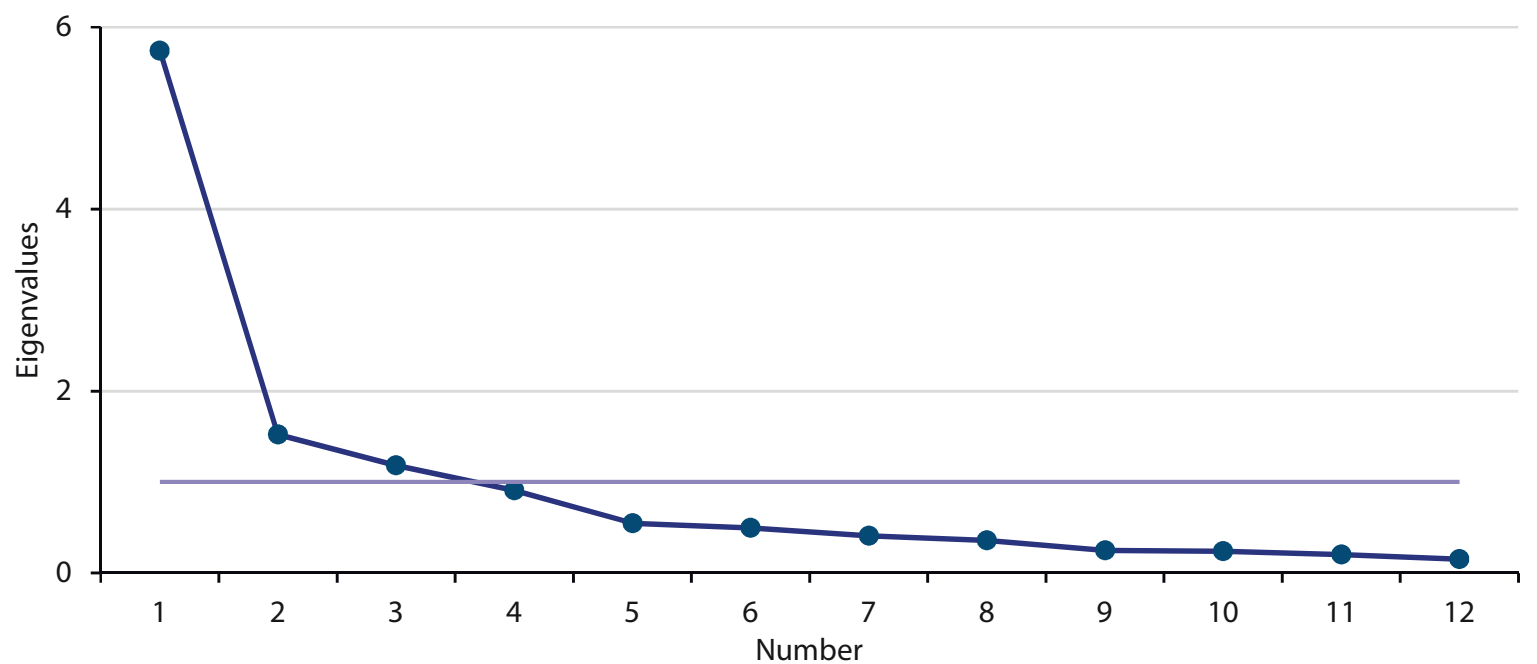

Fig. 1. Scree plot of eigenvalues

Source: authors' calculations based on PRS-Group institutional data

"Religious Tensions" and "Ethnic Tensions" indicators. All of them show external and internal conflicts, in which a country is involved, together with military in politics that can be used for conflicts regulation. Therefore, the second component refers to "Conflicts and external policy".

The third component comprises "Government Stability" and "Democratic Accountability" indicators, which refer to "Government Stability" indicator.

The efficiency of the principal component analysis has been tested with the Kaiser-MeyerOlkin measure $[55,56]$. The sampling is considered to be adequate if the value of this measure is greater than 0.5 . The transformation of 12 indices into three common indicators appears to be efficient since the obtained value of sampling adequacy is equal to 0.87 (according to authors' calculations in Stata).

\section{Poisson Pseudo Maximum Likelihood Regression}

After the principal component analysis, the whole dataset was divided into four subsets according to the development of the countries:

- developed FDI-recipient and FDI-investing countries;

- developed FDI-recipient and developing $F D I$-investing countries;

- developing FDI-recipient and developed FDI-investing countries;

- developing FDI-recipient and FDI-investing countries.

The division of the countries was accomplished based on the United Nations Conference on Trade and Development (UNCTAD) classification of countries' development.

First, we provide estimation results for Poisson Pseudo Maximum Likelihood method with instru- mental variables (IV PPML) in order to evaluate the model. To check the obtained results for robustness, we implement Poisson Pseudo Maximum Likelihood (PPML) and estimate the model excluding one control variable using IV PPML.

Table 5 presents the results of Poisson Pseudo Maximum Likelihood with instrumental variables (IV PPML). It is one of the methods developed by Silva and Tenreyro for estimating the gravity model, which considers both positive and negative values of a dependent variable. It allows avoiding the exclusion of data with negative values from the dataset. Indicators of a legal system's historical belonginbelonging to a legal system - AngloSaxon, German, French, or Scandinavian -are implemented as instrumental variables. According to the Hansen's J-statistics, the selected instrumental variables have strong power, and therefore are suitable for the analysis.

As we have previously mentioned, the gravity model has two assumptions according to the included variables. As it is represented in Table 5, the variables indicating the size of an economy have a positive impact on foreign direct investment. The distance between receiving and investing countries negatively affects foreign direct investment flows. Furthermore, all gravity variables are significant at $1 \%$ significance level. Therefore, all gravity variables are significant and have predictable signs.

However, after applying the instrumental approach, exchange rate became insignificant for most cases. All political stability indicators are insignificant for developed FDI-recipient countries and developed FDI-investor economies. Similar results are obtained for the situation, when both countries are referred to developing economies. For developed economies, when investing to de- 
Table 5

Estimation results: political stability's impact on foreign direct investment for four data subsets implementing IV PPML method

\begin{tabular}{|c|c|c|c|c|}
\hline Dependent variable FDI & $\begin{array}{c}\text { Developed } \\
\text { - developed }\end{array}$ & $\begin{array}{c}\text { Developed } \\
\text { - developing }\end{array}$ & $\begin{array}{c}\text { Developing } \\
\text { - developing }\end{array}$ & $\begin{array}{l}\text { Developing } \\
\text { - developed }\end{array}$ \\
\hline Logarithm of GDP importer country & $\begin{array}{l}2.982^{* *} \\
(1.421)\end{array}$ & $\begin{array}{l}0.063^{* *} \\
(0.035)\end{array}$ & $\begin{array}{l}0.088^{* * *} \\
(0.009)\end{array}$ & $\begin{array}{l}0.122^{* * *} \\
(0.006)\end{array}$ \\
\hline Logarithm of GDP exporter country & $\begin{array}{l}0.828^{* * *} \\
(0.151)\end{array}$ & $\begin{array}{l}0.132^{* * *} \\
(0.014)\end{array}$ & $\begin{array}{l}0.077^{* * *} \\
(0.006)\end{array}$ & $\begin{array}{l}0.150^{* * *} \\
(0.004)\end{array}$ \\
\hline Logarithm of distance & $\begin{array}{c}-0.777^{* * *} \\
(0.159)\end{array}$ & $\begin{array}{c}-0.097^{* * *} \\
(0.021)\end{array}$ & $\begin{array}{c}-0.195^{* * *} \\
(0.010)\end{array}$ & $\begin{array}{c}-0.062^{* * *} \\
(0.010)\end{array}$ \\
\hline Openness & $\begin{array}{c}0.063 \\
(0.044) \\
\end{array}$ & $\begin{array}{l}0.050^{* * *} \\
(0.017)\end{array}$ & $\begin{array}{c}-0.0009^{* * *} \\
(0.0003)\end{array}$ & $\begin{array}{c}-0.0009^{* * *} \\
(0.0003)\end{array}$ \\
\hline Inflation & $\begin{array}{c}-1.548^{* *} \\
(0.749)\end{array}$ & $\begin{array}{c}0.006 \\
(-0.015)\end{array}$ & $\begin{array}{l}-0.002 \\
(0.002)\end{array}$ & $\begin{array}{c}-0.004^{* * *} \\
(0.001)\end{array}$ \\
\hline Exchange rate & $\begin{array}{c}0.006 \\
(0.374) \\
\end{array}$ & $\begin{array}{c}0.0002 \\
(0.0003)\end{array}$ & $\begin{array}{l}-0.002 \\
(0.008)\end{array}$ & $\begin{array}{l}0.017^{* *} \\
(0.007)\end{array}$ \\
\hline $\begin{array}{l}\text { Government effectiveness in FDI- } \\
\text { recipient country }\end{array}$ & $\begin{array}{c}0.012 \\
(0.009)\end{array}$ & $\begin{array}{c}0.002^{*} \\
(0.0009)\end{array}$ & $\begin{array}{l}-0.0001 \\
(0.0005)\end{array}$ & $\begin{array}{l}-0.0006 \\
(0.0004\end{array}$ \\
\hline $\begin{array}{l}\text { Conflicts and external policy in FDI- } \\
\text { recipient country }\end{array}$ & $\begin{array}{l}-0.016 \\
(0.011)\end{array}$ & $\begin{array}{l}0.007^{* * *} \\
(0.001)\end{array}$ & $\begin{array}{l}0.0005 \\
(0.002)\end{array}$ & $\begin{array}{l}0.0003^{*} \\
(0.0002)\end{array}$ \\
\hline $\begin{array}{l}\text { Government Stability and Democracy } \\
\text { in FDI-recipient country }\end{array}$ & $\begin{array}{c}0.007 \\
(0.005) \\
\end{array}$ & $\begin{array}{l}-0.813^{*} \\
(0.434)\end{array}$ & $\begin{array}{l}0.0005 \\
(0.002)\end{array}$ & $\begin{array}{l}-0.010 \\
(0.021)\end{array}$ \\
\hline Constant & $\begin{array}{l}-49.243^{* *} \\
(24.723)\end{array}$ & $\begin{array}{l}-0.063^{*} \\
(0.035)\end{array}$ & $\begin{array}{c}-0.878^{* * *} \\
(0.237) \\
\end{array}$ & $\begin{array}{c}-1.427^{* * *} \\
(0.183)\end{array}$ \\
\hline Observations & 20795 & 37401 & 36986 & 21382 \\
\hline Hansen J. ( $p$-value) & 0.72 & 0.64 & 0.35 & 0.32 \\
\hline
\end{tabular}

Notes: Significance: ${ }^{*}<0.1 ;{ }^{* *}<0.05 ;{ }^{* * *}<0.01$; standard errors in parenthesis

Source: Authors' calculations based on data provided by International Monetary Fund, World Bank and PRS-Group.

veloping ones, such indicators as "Government effectiveness" and "Conflicts and external policy" are important. By the improvement of these political stability indicators, developed FDI-investors might increase outward direct investment to developing economies. However, "Government Stability and Democracy" index, which contains "Democracy accountability" and "Government Stability", has a negative impact on bilateral foreign direct investment flows between developed and developing countries. It can be explained by political issues that developed economies are seeking, as experience shows that less democratic economies can be influenced by the global international policy. Developing countries strive to invest into developed economies in order to get financial and right protection, therefore, "Conflicts and external policy" is a significant indicator. Meanwhile, many developing economies are facing the problem of internal and external conflicts, which decreases the political stability of the state and leads to outward investment to developed FDI-recipient countries.

After the main estimation, we provide PPML estimations for all datasets without instrumental variables in order to evaluate the model and check the estimation results for robustness. In addition, we check the model excluding exchange rate from the sample by applying IV PPML to examine the robustness of the results. The implementation of Poisson Pseudo Maximum Likelihood in the statistical package Stata for panel data does not allow working with dependent variables lying in the range below zero, therefore, all negative values were excluded from the dataset. For the subset aincluding developed countries is recipients of FDI and a developed countries as investors, 6 686 observations were excluded (30\% of the analysed series), which might exert the results. In case when a developed economy is an investor and a developing economy is a recipient, only $15 \%$ were excluded due to negative values of dependent variable. For a pair of countries, when both are developing, only $14 \%$ were excluded from the series. From the last subset, $16 \%$ of data were dropped due to negative values.

Nevertheless, the estimates obtained from Table 6 indicate the robustness of the econometric model. As we have previously mentioned, the gravity model has two assumptions according to the included variables. As it is represented in Table 6, all gravity models have expected signs 
Estimation results: political stability's impact on foreign direct investment

for four data subsets implementing PPML method

\begin{tabular}{|l|c|c|c|c|}
\hline \multicolumn{1}{|c|}{ Dependent variable FDI $\geq \mathbf{0}$} & $\begin{array}{c}\text { Developed } \\
- \text { developed }\end{array}$ & $\begin{array}{c}\text { Developed } \\
- \text { developing }\end{array}$ & $\begin{array}{c}\text { Developing } \\
- \text { developing }\end{array}$ & $\begin{array}{c}\text { Developing } \\
\text { - developed }\end{array}$ \\
\hline Logarithm of GDP importer country & $0.800^{* * *}(0.004)$ & $0.58^{* * *}(0.051)$ & $0.816^{* * *}(0.080)$ & $0.654^{* * *}(0.025)$ \\
\hline Logarithm of GDP exporter country & $0.563^{* * *}(0.031)$ & $0.57^{* *}(0.048)$ & $0.368^{* * *}(0.049)$ & $0.601^{* * *}(0.029)$ \\
\hline Logarithm of distance & $-0.528^{* * *}(0.036)$ & $-0.631^{* * *}(0.106)$ & $-1.199^{* * *}(0.075)$ & $-0.313^{* * *}(0 . .078)$ \\
\hline Openness & $0.012^{* * *}(0.002)$ & $0.009^{* * *}(0.002)$ & $-0.002(0.003)$ & $-0.008^{* * *}(0.002)$ \\
\hline Inflation & $-0.120^{* * *}(0.024)$ & $0.047(0.035)$ & $-0.093^{* * *}(.024)$ & $-0.059^{* * *}(0.010)$ \\
\hline Exchange rate & $-0.059^{* *}(0.029)$ & $-0.183^{* * *}(0.047)$ & $0.006(0.054)$ & $-0.017(0.026)$ \\
\hline $\begin{array}{l}\text { Government effectiveness in FDI- } \\
\text { recipient country }\end{array}$ & $0.0008^{* * *}(0.0003)$ & $0.002^{* * *}(0.0005)$ & $-0.0005(0.0005)$ & $0.0007^{* * *}(0.0003)$ \\
\hline $\begin{array}{l}\text { Conflicts and external policy in FDI- } \\
\text { recipient country }\end{array}$ & $-0.0002(0.0002)$ & $-0.0009^{*}(0.0005)$ & $0.001(0.0008)$ & $0.0005(0.0005)$ \\
\hline $\begin{array}{l}\text { Government Stability and } \\
\text { Democracy in FDI-recipient country }\end{array}$ & $-0.0008^{* * *}(0.0002)$ & $0.0007(0.0005)$ & $0.0009(0.0006)$ & $-.001^{* * *}(0 . .0003)$ \\
\hline Constant & $-7.711^{* * *}(0.716)$ & $-6.382^{* * *}(1.277)$ & $-0.370(1.259)$ & $-7.040^{* * *}(0.748)$ \\
\hline Observations & 14109 & 31556 & 31626 & 17788 \\
\hline Pseudo $R$ sq. & 0.19 & 0.024 & 0.14 & 0.13 \\
\hline
\end{tabular}

Notes: Significance: ${ }^{*}<0.1 ;{ }^{* *}<0.05 ;{ }^{* * *}<0.01$; standard errors in parenthesis

Source: Authors' calculations based on data provided by International Monetary Fund, World Bank and PRS-Group.

Table 7

Estimation results: robustness check for political stability's impact on foreign direct investment for four data subsets implementing IV PPML method

\begin{tabular}{|l|c|c|c|c|}
\hline \multicolumn{1}{|c|}{ Dependent variable FDI $\geq \mathbf{0}$} & $\begin{array}{c}\text { Developed } \\
- \text { developed }\end{array}$ & $\begin{array}{c}\text { Developed } \\
- \text { developing }\end{array}$ & $\begin{array}{c}\text { Developing } \\
- \text { developing }\end{array}$ & $\begin{array}{c}\text { Developing } \\
- \text { developed }\end{array}$ \\
\hline Logarithm of GDP importer country & $2.982^{* *}(1.277)$ & $5.035^{* *}(3.177)$ & $0.086^{* *}(0.047)$ & $0.097^{* *}(0.052)$ \\
\hline Logarithm of GDP exporter country & $0.828^{* * *}(0.160)$ & $0.971^{* * *}(9.276)$ & $0.074^{* *}(0.013)$ & $0.085^{* *}(0.034)$ \\
\hline Logarithm of distance & $-0.777^{* *}(0.218)$ & $-2.300^{* *}(2.504)$ & $-0.203^{* *}(0.012)$ & $-0.033^{* *}(0.012)$ \\
\hline Openness & $0.063(0.039)$ & $0.068^{* *}(1.232)$ & $-0.001^{* *}(0.003)$ & $-0.0009^{* *}(0.0002)$ \\
\hline Inflation & $-1.548^{*}(0.806)$ & $-2.283(4.715)$ & $-0.002(0.003)$ & $-0.003(0.002)$ \\
\hline $\begin{array}{l}\text { Government effectiveness in FDI- } \\
\text { recipient country }\end{array}$ & $0.012(0.011)$ & $0.006^{*}(0.413)$ & $-0.001(0.003)$ & $-0.0005(0.0003)$ \\
\hline $\begin{array}{l}\text { Conflicts and external policy in FDI- } \\
\text { recipient country }\end{array}$ & $-0.016(0.011)$ & $0.004^{*}(0.368)$ & $0.003(0.002)$ & $0.0001^{*}(0.0001)$ \\
\hline $\begin{array}{l}\text { Government Stability and Democracy } \\
\text { in FDI-recipient country }\end{array}$ & $0.007(0.006)$ & $-0.006^{*}(0.037)$ & $0.002(0.002)$ & $-0.074(0.021)$ \\
\hline Constant & $-49.243^{* *}(22.25)$ & -71.486 & $-1.128^{* *}(0.097)$ & $-1.427^{* *}(0.174)$ \\
\hline Observations & 20795 & 37401 & 36986 & 21382 \\
\hline Hansen J. $(p-v a l u e)$ & 0.69 & 0.62 & 0.31 & 0.29 \\
\hline
\end{tabular}

Notes: Significance: ${ }^{*}<0.1 ;{ }^{* *}<0.05 ;{ }^{* * *}<0.01$; standard errors in parenthesis

Source: Authors' calculations based on data provided by International Monetary Fund, World Bank and PRS-Group.

and significance: the variables indicating the size of an economy have a statistically significant positive impact on foreign direct investment, while distance negatively affects foreign direct investment flows. Furthermore, all gravity variables are significant at $1 \%$ significance level. Openness is a significant factor in most cases; however, it has a positive impact only on developed economies. It can be explained that for developing countries, it is more difficult to compete with highly competitive transnational companies from the developed countries, therefore, despite the higher openness rates in developed countries, the more it increases, the less investing power companies from developing economies have. It is worth to mention that the indicator of trade openness is insignificant be- 
tween developing economies. The magnitude of inflation in the country predictably has a statistically significant negative impact on the inflow of direct investment from the country. According to the results, exchange rate is insignificant for developing economies. Institutional indicators show unexpected results from the implemented PPML. Nevertheless, it can be asserted that "Government effectiveness" in most cases has a positive and significant impact on foreign direct investment flows for all countries. Another two indicators, according to these results, "Conflicts and external policy" and "Government Stability and Democracy" are facing struggles for interpretation, due to the change of signs. Additionally, "Conflicts and external policy" is insignificant in the analysis for most of the country pairs.

According to the estimations resulting from the implementation of IV PPML, the exclusion of exchange rate from the model did not influence the regression analysis output, which can be observed in Table 7.

\section{Conclusion}

The article focuses on estimating the impact of political stability on foreign direct investment flows. Theoretically, the level of political stability of both FDI-recipient and FDI-investing countries indirectly characterises the level of costs of doing business in countries. Therefore, the provision of better institutional environment should have a positive effect on foreign direct investment flows between the countries.

Major empirical studies confirm the positive impact of political stability on foreign direct investment flows. Meanwhile, many studies do not take into account the most important factors that can lead to biased estimates, ignoring the problem of endogeneity or not accounting for the gravity approach (or just excluding such FDI determinants as distance between countries and the size of the exporting country).

Implementing the gravity approach to model bilateral foreign direct investment flows, Poisson Pseudo Maximum Likelihood method with instrumental variables, and the principal components analysis to examine various aspects of institutional development, we found that for countries of the same development level there is no unambiguous confirmation of the hypotheses about the positive impact of political stability on foreign direct investment flows. Considering the bilateral foreign direct investment between developed economies, political stability indicators are insignificant at all. Similar result was obtained for foreign direct investment flows between develop- ing countries. Institutional variables are important only for countries with different development levels, which confirms the hypothesis that countries' development level affects FDI flows between them. However, we also found the difference in factors' significance for developed FDI-investors and developing FDI-investors. For developed $F D I$-investors, all political stability indicators are significant, when investing FDI to developing economies. Simultaneously, such indicators as "Government effectiveness" and "Conflicts and external policy" have a positive and significant influence on foreign direct investment flows between developed and developing countries. These indicators are important for developed FDIinvestors. However, "Government Stability and Democracy" has a negative impact on foreign direct investment flows. That might be caused by lower level of democracy in a FDI-recipient country, which gives companies from developed economies more flexibility and opportunity to set their right, or it might be associated with political issues, which are nowadays raised in many developing economies. Considering FDI flows from developing to developed economies, "Government effectiveness" and "Government Stability and Democracy" appeared to be insignificant, while "Conflicts and external policy" positively and statistically affects foreign direct investment flows. To summarise, in most cases, the improvement of political stability leads to an increase in foreign direct investment. It is necessary to mention that the econometric analysis was conducted based on the gravity approach and implementation of the IV PPML method, which provide unbiased and relevant results that can be used by countries' governments in order to improve institutional environment and enhance political stability in the country. The government policy should take into account the significance of institutional environment. Coincidently, the government policy on FDI attraction should be aimed at the countries with different development level. Thus, the establishment of institutional quality improvement programmes in developing economies will spur FDI inflows from developed countries.

At the same time, it is necessary to consider other macroeconomic factors when investing to the country of the same development level; therefore, the main conclusion reached in this study is that the influence of political on the inflow of foreign direct investment is not exaggerated. Still, with a high degree of probability, it can be argued that other factors are of higher priority for foreign companies to make decisions on foreign direct investment. 


\section{References}

1. Akhmetzaki, Ye. Zh. \& Mukhamediyev, B. M. (2017). FDI Determinants in the Eurasian Economic Union Countries and Eurasian Economic Integration Effect on FDI Inflows. Ekonomika regiona [Economy of Region], 13(3), 959-970.

2. Borensztein, E., De Gregorio, J. \& Lee, J.-W. (1998). How does foreign direct investment affect economic growth? Journal of International Economics, 45(1), 115-135. DOI: 10.1016/S0022-1996(97)00033-0.

3. Acemoglu, D. \& Johnson, S. (2005). Unbundling Institutions. Journal of Political Economy, 113(5), 949-995. DOI: $10.1086 / 432166$.

4. Buchanan, B. G., Le, Q. V. \& Rishi, M. (2012). Foreign direct investment and institutional quality: Some empirical evidence. International Review of Financial Analysis, 21, 81-89. DOI: 10.1016/j.irfa.2011.10.001.

5. Daude, C. \& Stein, E. (2007). The quality of institutions and foreign direct investment. Economics \& Politics, 19(3), 317-344. DOI: 10.1111/j.1468-0343.2007.00318.x.

6. Leibrecht, M. \& Riedl, A. (2014). Modeling FDI based on a spatially augmented gravity model: Evidence for Central and Eastern European Countries. The Journal of International Trade \& Economic Development, 23(8), 1206-1237. DOI: 10.1080/09638199.2013.861006.

7. Azeem, S. W., Hussain, H. \& Hussain, R. Y. (2012). The determinants of foreign investment in pakistan: a gravity model analysis. LogForum, 8(2), 81-97.

8. Çeviş, İ. \& Camurdan, B. (2007). The economic determinants of foreign direct investment in developing countries and transition economies. The Pakistan Development Review, 46(3), 285-299. DOI: 10.30541/v46i3pp.285-299.

9. Folfas, P. (2011). FDI between EU member states: gravity model and taxes. ETSG 2011 Copenhagen.

10. Borrmann, C., Jungnickel, R. \& Keller, D. (2005). What gravity models can tell us about the position of German FDI in Central and Eastern Europe. HWWA Discussion Paper No.328. DOI: 10.2139/ssrn.798924.

11. Noorbakhsh, F., Paloni, A. \& Youssef, A. (2001). Human capital and FDI inflows to developing countries: New empirical evidence. World Development, 29(9), 1593-1610. DOI: 10.1016/S0305-750X(01)00054-7.

12. Wheeler, D. \& Mody, A. (1992). International investment location decisions: The case of US firms. Journal of International Economics, 33(1-2), 57-76. DOI: 10.4324/9780203966143.

13. Melitz, M. J. (2003). The impact of trade on intra-industry reallocations and aggregate industry productivity. Econometrica, 71(6), 1695-1725. DOI: 10.1111/1468-0262.00467.

14. Mayer, T. \& Zignago, S. (2012). Notes on CEPII's distances measures: The GeoDist database. CEPII Working Paper No. 2011-25. DOI: 10.2139/ssrn.1994531.

15. Brock, G. J. (1998). Foreign direct investment in Russia's regions 1993-95. Why so little and where has it gone? Economics of Transition, 6(2), 349-360. DOI: 10.1111/j.1468-0351.1998.tb00053.x.

16. Doytch, N. (2021). Do FDI inflows to Eastern Europe and Central Asia respond to the business cycle? A sector level analysis. The Journal of Economic Asymmetries, 23, e00194. DOI: 10.1016/j.jeca.2020.e00194.

17. Wang, Z. Q. \& Swain, N. J. (1995). The determinants of foreign direct investment in transforming economies: Empirical evidence from Hungary and China. Weltwirtschaftliches Archiv, 131(2), 359-382. DOI: 10.1007/BF02707440.

18. Mariev, O. S., Drapkin, I. M., Chukavina, K. V. \& Rachinger, H. (2016). Determinants of FDI inflows: The case of Russian regions. Ekonomika regiona [Economy of Region], 12(4), 1244-1252. DOI: https://doi.org/10.17059/2016-4-24

19. Markusen, J. R. (2005). Modeling the Offshoring of White-Collar Services: From Comparative Advantage to the New Theories of Trade and Foreign Direct Investment. Brookings Trade Forum, 2005(1), 1-23. DOI: 10.1353/btf.2006.0019.

20. Schneider, F. \& Frey, B. S. (1985). Economic and political determinants of foreign direct investment. World Development, 13(2), 161-175. DOI: 10.1016/0305-750X(85)90002-6.

21. Gastanaga, V. M., Nugent, J. B. \& Pashamova, B. (1998). Host country reforms and FDI inflows: How much difference do they make? World Development, 26(7), 1299-1314. DOI: 10.1016/S0305-750X(98)00049-7.

22. Wei, S.-J. (2000). How taxing is corruption on international investors? Review of Economics and Statistics, 82(1), 1-11. DOI: 10.1162/003465300558533.

23. Jensen, N. (2003). Democratic Governance and Multinational Corporations: Political Regimes and Inflows of Foreign Direct Investment. International Organization, 57(3), 587-616. DOI: 10.1017/s0020818303573040.

24. JAhlquist, J. S. (2006). Economic Policy, Institutions, and Capital Flows: Portfolio and Direct Investment Flows in Developing Countries. International Studies Quarterly, 50(3), 681-704. DOI:10.1111/j.1468-2478.2006.00420.x.

25. Asiedu, E. (2006). Foreign Direct Investment in Africa: The Role of Natural Resources, Market Size, Government Policy, Institutions and Political Instability. The World Economy, 29(1), 63-77. DOI: 10.1111/j.1467-9701.2006.00758.x.

26. Gani, A. (2007). Governance and foreign direct investment links: evidence from panel data estimations. Applied Economics Letters, 14(10), 753-756 DOI: 10.1080/13504850600592598.

27. Knack, S. \& Keefer, P. (1995). Institutions and economic performance: cross-country tests using alternative institutional measures. Economics \& Politics, 7(3), 207-227. DOI: 10.1111/j.1468-0343.1995.tb00111.x.

28. Globerman, S. \& Shapiro, D. (2002). Global foreign direct investment flows: The role of governance infrastructure. World Development, 30(11), 1899-1919. DOI: 10.1016/S0305-750X(02)00110-9.

29. Buch, C. M., Kleinert, J., Lipponer, A., Toubal, F. \& Baldwin, R. (2005). Determinants and effects of foreign direct investment: evidence from German firm-level data. Economic Policy, 20(41), 52-110. DOI: 10.1111/j.1468-0327.2005.00133.x. 
30. Djankov, S., La Porta, R., Lopez-de-Silanes, F. \& Shleifer, A. (2002). The regulation of entry. The Quarterly Journal of Economics, 117(1), 1-37. DOI: 10.1162/003355302753399436.

31. Djankov, S. (2009). The regulation of entry: A survey. The World Bank Research Observer, 24(2), 183-203. DOI: 10.1093/wbro/lkp005.

32. Djankov, S., La Porta, R., Lopez-de-Silanes, F. \& Shleifer, A. (2008). The law and economics of self-dealing. Journal of Financial Economics, 88(3), 430-465. DOI: 10.1525/fsr.2020.33.1-2.128.

33. Ali, F. A., Fiess, N. \& MacDonald, R. (2010). Do institutions matter for foreign direct investment? Open Economies Review, 21(2), 201-219. DOI: 10.1007/s11079-010-9170-4.

34. Biswas, R. (2002). Determinants of foreign direct investment. Review of Development Economics, 6(3), $492-504$. DOI: $10.1111 / 1467-9361.00169$.

35. Bénassy-Quéré, A., Coupet, M. \& Mayer, T. (2007). Institutional determinants of foreign direct investment. World Economy, 30(5), 764-782. DOI: 10.1111/j.1467-9701.2007.01022.x.

36. Polyxeni, K. \& Theodore, M. (2019). An empirical investigation of FDI inflows in developing economies: Terrorism as a determinant factor. The Journal of Economic Asymmetries, 20, e00125. DOI: 10.1016/j.jeca.2019.e00125.

37. Hájková, P., Zemanová, B., Roche, K. \& Hájek, B. (2009). An evaluation of field and noninvasive genetic methods for estimating Eurasian otter population size. Conservation Genetics, 10(6), 1667-1681. DOI: 10.1007/s10592-008-9745-4.

38. Asiedu, E. (2002). On the Determinants of Foreign Direct Investment to Developing Countries: Is Africa Different? World Development, 30(1), 107-119. DOI: 10.1016/S0305-750X(01)00100-0.

39. Brunetti, A. \& Weder, B. (1998). Investment and institutional uncertainty: a comparative study of different uncertainty measures. Weltwirtschaftliches Archiv, 134(3), 513-533. DOI: 10.1007/bf02707928.

40. Li, Q. \& Resnick, A. (2003). Reversal of fortunes: Democratic institutions and foreign direct investment inflows to developing countries. International Organization, 57(1), 175-212. DOI: 10.1017/s0020818303571077.

41. Asiedu, E. (2013). Foreign direct investment, natural resources and institutions. International Growth Centre, 3, $1-38$.

42. Tinbergen, J. (1962). Shaping The World Economy; Suggestions For An International Economic Policy. New York: The Twentieth Century Fund, 330.

43. Brainard, S. L. (1997). An empirical assessment of the proximity-concentration trade-off between multinational sales and trade. The American Economic Review, 87(4), 520-544.

44. Mundell, R. A. (1957). International trade and factor mobility. The American Economic Review, 47(3), 321-335.

45. Markusen, J. R. (2004). Multinational firms and the theory of international trade. Cambridge: MIT press, 682. DOI: 10.7551/mitpress/4797.001.0001.

46. Helpman, E. (1984). A simple theory of international trade with multinational corporations. Journal of Political Economy, 92(3), 451-471. DOI: 10.1086/261236.

47. Helpman, E. \& Krugman, P. R. (1985). Market structure and foreign trade: Increasing returns, imperfect competition, and the international economy. Cambridge: MIT press, 283.

48. Grossman, G. M., Helpman, E. \& Szeidl, A. (2006). Optimal integration strategies for the multinational firm. Journal of International Economics, 70(1), 216-238. DOI: 10.1016/j.jinteco.2005.07.011.

49. Helpman, E., Melitz, M. J. \& Yeaple, S. R. (2004). Export versus FDI with heterogeneous firms. American Economic Review, 94(1), 300-316. DOI: 10.1257/000282804322970814.

50. Campos, N. F. \& Kinoshita, Y. (2008). Foreign direct investment and structural reforms: Evidence from Eastern Europe and Latin America. IMF Working Papers, 38. DOI: 10.5089/9781451868883.001.

51. Silva, J. M. C. S. \& Tenreyro, S. (2006). The log of gravity. The Review of Economics and Statistics, 88(4), $641-658$. DOI: $10.1162 /$ rest.88.4.641.

52. Mariev, O., Drapkin, I. \& Chukavina, K. (2016). Is Russia successful in attracting foreign direct investment? Evidence based on gravity model estimation. Review of Economic Perspectives, 16(3), 245-267. DOI: 10.1515/revecp-2016-0015.

53. Bitar, N., Hamadeh, M. \& Khoueiri, R. (2020). Impact of Political Instability on Foreign Direct Investment in Lebanon. Asian Social Science, 16(1), 41-48. https://dx.doi.org/10.5539/ass.v16n1p41.

54. Júlio, P., Pinheiro-Alves, R. \& Tavares, J. (2013). Foreign direct investment and institutional reform: evidence and an application to Portugal. Portuguese Economic Journal, 12(3), 215-250. DOI: 10.1007/s10258-013-0093-z.

55. Kaiser, H. F. (1970). A second generation little jiffy. Psychometrika, 35(4), 401-415. DOI: 10.1007/BF02291817.

56. Kaiser, H. F. (1974). An index of factorial simplicity. Psychometrika, 39(1), 31-36. DOIDOI: 10.1007/BF02291575.

\section{About the authors}

Rogneda I. Vasilyeva - Assistant of the Academic Department of Economics, Junior Research Associate of the Laboratory for International and Regional Economics, Graduate School of Economics and Management, Ural Federal University; https://orcid.org/0000-0001-5539-3145 (25, Gogolya St., Ekaterinburg, 620075, Russian Federation; e-mail: rogneda.groznykh@urfu.ru).

Oleg S. Mariev - Cand. Sci. (Econ.), Associate Professor, Head of the Academic Department of Economics, Graduate School of Economics and Management, Ural Federal University; Scopus Author ID: 55764909000; https://orcid.org/00000002-9745-8434 (19, Mira St., Ekaterinburg, 620002, Russian Federation; e-mail: o.s.mariev@urfu.ru). 


\section{Информация об авторах}

Васильева Рогнеда Ивановна - ассистент кафедры экономики, младший научный сотрудник Лаборатории международной и региональной экономики, Институт экономики и управления, Уральский федеральный университет имени первого Президента России Б. Н. Ельцина; https://orcid.org/0000-0001-5539-3145 (Российская Федерация, 62000275, г. Екатеринбург, ул. Гоголя, 25; e-mail: rogneda.groznykh@urfu.ru).

Мариев Олег Святославович - кандидат экономических наук, доцент, заведующий кафедрой экономики, Уральский федеральный университет имени первого Президента России Б. Н. Ельцина; Scopus Author ID: 55764909000; https://orcid.org/0000-0002-9745-8434 (Российская Федерация, 620002, г. Екатеринбург, ул. Мира 19; e-mail: o.s.mariev@urfu.ru).

Дата поступления рукописи:: 24.03.21. Прошла рецензирование: 25.04.21. Принято решение о публикации: 24.09.2021. Received: 24 March 2021. Reviewed: 25 Apr 2021. Accepted: 24 Sep 2021. 